\title{
Mineral status of plants and soil in silver fir stands of the Silesian and Żywiec Beskidy (Western Carpathians)
}

\author{
Jacek Borgulat ${ }^{1,{ }^{*}}$, Tomasz Staszewski ${ }^{1}$, Włodzimierz Łukasik $^{1}$, and Lukasz Jałowiecki ${ }^{1}$ \\ ${ }^{1}$ Institute for Ecology of Industrial Areas, Kossutha 6, 40-844 Katowice, Poland
}

\begin{abstract}
For last decades the Silesian and Żywiec Beskidy have been affected by different types of anthropopression. Up to the nineties of the 20th century, forests of the area were affected by a high level of air pollutants transported mainly from the Upper Silesian and Ostrava industrial regions. From 2004 intensive felling and skidding works in declining forest stands combined with their reconstruction have been carried out. Among different species silver fir has been introduced on a large scale. In the paper the results of investigation of plants and soil carried out 7 sites located in Beskidy Mountains (49 $\left.41^{\prime} 6^{\prime \prime} \mathrm{N}, 19^{\circ} 1^{\prime} 48^{\prime \prime} \mathrm{E}\right)$ are presented. Contents of $\mathrm{K}, \mathrm{Mg}, \mathrm{Ca}$ and $\mathrm{N}$ in needles of silver fir (Abies alba Mill.) and leaves of bilberry (Vaccinium myrtillus L.) were determined which was accompanied by a chemical characteristics of forest topsoil from the same sites. Moreover, in both environment compartments, the concentration of $\mathrm{S}, \mathrm{Pb}, \mathrm{Cd}$, and $\mathrm{Zn}$ was also determined to assess the level of anthropopression in individual sites. In general, the obtained results show relatively good mineral status of plants. Some disturbances in the ratios of elements in plants were found in sites located near the Polish and Czech border. In plants and soil in these sites an elevated level of heavy metals was found which testifies the transboundary transport of air pollutants. The bilberry seems to be a better bioindicator of heavy metal pollution than silver fir.
\end{abstract}

\section{Introduction}

Development of Silesian industry in the 19th century became the reason for clearcutting thousand hectares of forests. Monocultures of quickly growing spruce were planted on habitats of beech, beech-fir and beech-fir-spruce forests within the area of the Western Carpathians. Spruce seeds of alien origin were often used for establishment of artificial forests promoted by economy. However, they were not adapted to climatic-habitat conditions and the quality of these forests became getting worse because of the local air pollution. Several successive years of droughts followed by the borer gradation resulted in the spruce forest dieback. At the beginning of the 21st century, a large-scale felling of artificial spruce (Picea abies) stands has begun. This situation needs the stand reconstruction which is assessed to comprise 5500 ha. It is assumed that such approach will

${ }^{*}$ Corresponding author: j.borgulat@ietu.katowice.pl 
result in adequacy of species composition with habitat. The intensive introduction of beech and fir in the Silesian and Żywiec Beskid area [1] is one of the most important measures.

The aim of this study was to characterize the soil which new seedlings of silver fir were planted in and mineral status of silver fir (Abies alba Mill.) needles and leaves of bilberry (Vaccinium myrtillus L.) which dominates plant life forms in the herbaceous layer of the investigated area. An attempt was also made to compare the ability of both plant species to accumulate elements of anthropogenic origin $(\mathrm{Pb}, \mathrm{Cd}, \mathrm{Zn}, \mathrm{S})$. The accumulation of elements in a foliage of bilberry has been widely used in environmental monitoring [2-5] but information on the use of fir needles as a bioindicator of anthropogenic emissions is very scarce $[6,7]$.

\section{Materials and methods}

\subsection{The study area and field sampling}

\subsubsection{Study area}

Plants and soil were collected from 2 Forest Districts - Wisła and Ujsoły. Both sites belong to the Beskid Śląski and Żywiec Landscape Parks (Fig. 1).
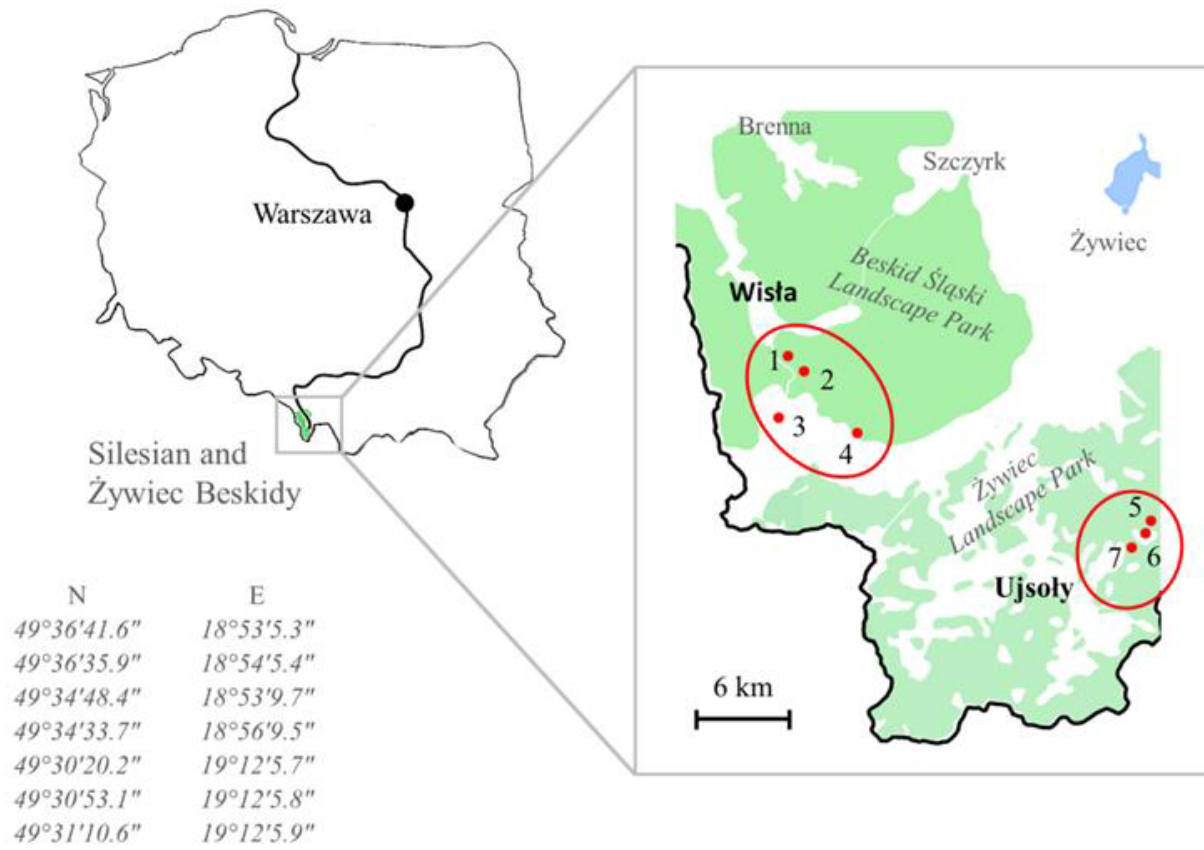

Fig. 1. Location of study area.

In Wisła Forest District samples were taken from four sites where intensive reconstruction of stands towards silver fir ( $A$. alba Mill.) has been carried out. The investigated area is affected by emissions from domestic heating, tourist traffic and long distance emissions from Ostrava (Czech Republic) and Upper Silesian Industrial Region. 
In Ujsoły Forest District soil and plants were collected in 3 areas where silver fir seedlings were planted. The area is located close to the Polish and Slovak border and it is considered as a "clean region" where air pollutants origin only from local domestic heating.

\subsubsection{Sample collection}

In each site, after litter and humus removal, $20 \mathrm{~cm}$ layers of soil (A-horizon) were collected. Six soil sub-samples were combined in a composite sample. It was accompanied by the sampling of plant material in the neighbourhood of the sampled soil. Current year needles were sampled from six approximately 15-year-old silver fir (Abies alba Mill.) trees. An average sample was taken for the analysis. The fully matured, undamaged leaves were detached from 20 shoots of bilberry (Vaccinium myrtillus L.) and pooled into one sample per site. All samples were collected in September.

\subsection{Physicochemical Analyses}

\subsubsection{Soil}

The soil material taken from A horizons was air-dried and sieved through a sieve with $1 \mathrm{~mm}$ mesh. Each mixed sample was examined for the following physico-chemical parameters: the $\mathrm{pH}$ values $\left(\mathrm{pH}\right.$ in $\mathrm{H}_{2} \mathrm{O}$ and $\mathrm{pH}$ in $1 \mathrm{M} \mathrm{KCl}$ ) were measured by a $\mathrm{pH}$-meter according to PNISO 10390:1997, determination exchangeable cations ( $\mathrm{Na}, \mathrm{K}, \mathrm{Mg}, \mathrm{Ca}$ ) according to PN-ISO 23470, Digestion of the samples in order to obtain total content of heavy metals $(\mathrm{Zn}, \mathrm{Cd}, \mathrm{Pb})$ was performed using aqua regia, and the metals were determined by ICP method according to PB-05/1.

\subsubsection{Plant}

Plant material was ground and mineralized with mixture of perchloric acid and nitric acid (1:4) in the MDS 2000 microwave system. The contents of $\mathrm{Na}$ and $\mathrm{K}$ were determined by the AAS method (SpectraAA 300 Varian). The contents of $\mathrm{Cd}, \mathrm{Zn}, \mathrm{Pb}, \mathrm{Mg}$ and $\mathrm{Ca}$ were determined by the ICP method with an ultrasonic nebulizer, total $\mathrm{N}$ was measured using the Kjeldahl method according to PN-ISO 11261:2002, S was measured using an IR detector (according to PN-G-04558:2001 and PN-EN 15407:2011, respectively).

The analyses of plant and soil were carried out in a certified laboratory of the Institute for Ecology of Industrial Areas, Katowice (Certificate No AB 325). Statistical analysis was made by STATISTICA (StatSoft, lnc. 2011, ver.12).

\section{Results and Discussion}

\subsection{The content of -micro and -macro elements in leaves and soil}

Nutritional status of trees is commonly determined by chemical analysis of leaves. In contrast with such species like spruce and beech, the most frequently planted species in the Beskids forests, there is very scarce information on the optimal or deficit concentrations of micro- and macroelements in silver fir needles. 

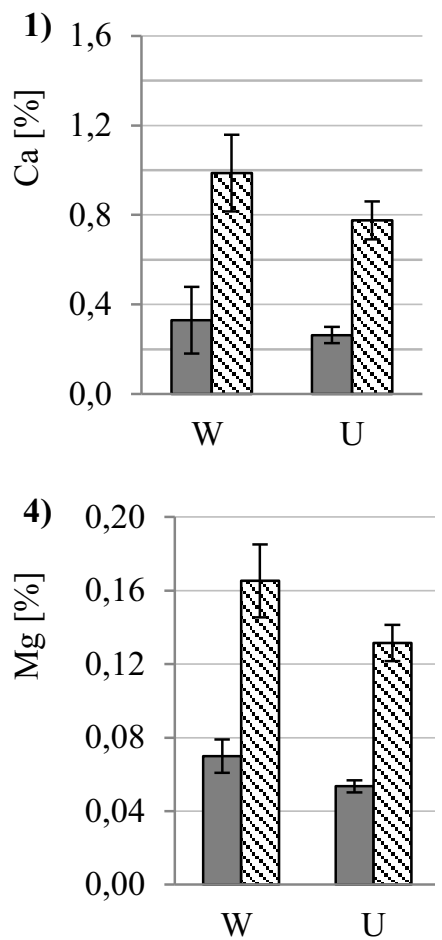
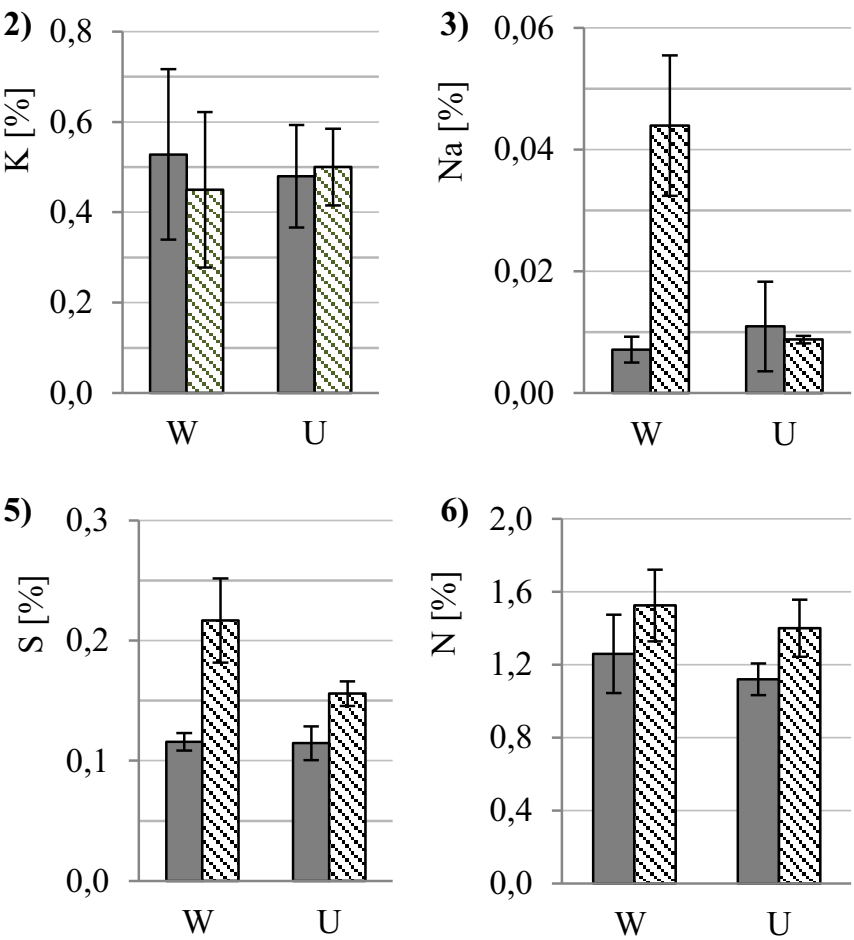

$\square$ A. alba $\square$ V. myrtillus

Fig. 1-6. Contents of $\mathrm{Ca}, \mathrm{K}, \mathrm{Na}, \mathrm{Mg}, \mathrm{S}$ and $\mathrm{N}$ in needles of silver fir (Abies alba Mill.) and leaves of bilberry (Vaccinium myrtillus L.) (Mean \pm SD; W-Wisła Forest District; U-Ujsoły Forest District).

Contents of macroelement in bilberry and silver fir leaves is presented in Figures 1-6. N is an essential nutrient for plant growth, development and reproduction. Its deficiency most often results in stunted growth, slow growth, and chlorosis.

Similar N concentrations in silver fir needles was found for both sites. They amounted to $1.22 \%$ and $1.12 \%$ in Wisła and Ujsoły Forest Inspectorate, respectively (Fig. 3). These values are in the range of nitrogen concentration found by other authours. In Sumava where silver fir has been also reintroduced, $\mathrm{N}$ concentration ranged from $0.95 \%$ to $2.15 \%$ (mean $1.39 \%$ ) [6]. The concentration in the range of $1.1 \%$ to $1.25 \%$ were found in Germany and Slovakia $[8,9]$.

The regulation of water regime is one of the most important functions of $\mathrm{K}$ and this is also important in the resistance of individual tree species to different stresses (e.g. resistance to frost) [6]. It was found that needles taken from weakened firs contain less $\mathrm{K}$ than the vital ones [10]. $\mathrm{K}$ content in silver fir needles from Bohemian Forest ranged from $0.3 \%$ to $1.1 \%$ [6]. In other investigations the mean $\mathrm{K}$ content in needles varied from $0.6 \%$ (Slovakia) to $0.8 \%$ (Poland) [9] and in Germany, the mean value in the fir needles was found to be $0.77 \%[8,11]$.

Hüttl [12] reported a deficiency limit value of $0.4-0.45 \%$ for potassium in silver fir. The obtained results for Wisła and Ujsoły - 0.48 and $0.52 \%$, respectively show that the concentration of $\mathrm{K}$ is close to a deficiency limit (Fig. 2.), which can result in weak plant development of this species.The concentration of $\mathrm{K}$ in the investigated soils $\left(4.3-4.9 \mathrm{mg} \cdot 100 \mathrm{~g}^{-1}\right)$ does not show its shortage for plants. It was addressed by Zawada [10] that despite the availibility of $\mathrm{K}$ in the soil, the weakned silver fir trees do not uptake this 
element in a sufficient quantity. It should be expected that other factor can be responsible for the deficit of this element in silver fir needles.

Tab. 1. Soil physicochemical analysys (SD-standard deviation, W-Wisła Forest District; U-Ujsoły Forest District).

\begin{tabular}{|c|c|c|c|c|c|c|c|c|c|c|}
\hline \multirow{2}{*}{\multicolumn{2}{|c|}{ Site }} & $\mathbf{C a}$ & $\mathbf{K}$ & $\mathbf{N a}$ & $\mathrm{Mg}$ & $\mathbf{Z n}$ & Cd & $\mathbf{P b}$ & \multirow{2}{*}{$\begin{array}{l}\text { pH } \\
\mathbf{H}_{2} \mathbf{O}\end{array}$} & \multirow{2}{*}{$\begin{array}{c}\mathbf{p H} \\
\mathbf{K C l}\end{array}$} \\
\hline & & \multicolumn{4}{|c|}{$\left[\mathrm{mg} \cdot 100 \mathrm{~g}^{-1}\right]$} & \multicolumn{3}{|c|}{$\left[\mathrm{mg} \cdot \mathrm{kg}^{-1}\right]$} & & \\
\hline \multirow{2}{*}{ W } & mean & 7.88 & 4.90 & 0.82 & 1.78 & 35.3 & 0.54 & 69.1 & 4.2 & 3.3 \\
\hline & $\pm \mathrm{SD}$ & 3.3 & 2.4 & 0.4 & 1.1 & 16 & 0.2 & 13 & 0.2 & 0.2 \\
\hline \multirow{2}{*}{$\mathrm{U}$} & mean & 11.3 & 4.30 & 0.63 & 2.85 & 67.6 & 0.52 & 39.3 & 5.0 & 4.0 \\
\hline & $\pm \mathrm{SD}$ & 6.9 & 1.7 & 0.1 & 2.1 & 11 & 0.1 & 21 & 0.2 & 0.2 \\
\hline
\end{tabular}

$\mathrm{Mg}$ is one of the most important nutrients involved in many enzyme activities and the structural stabilization of tissues. Its deficiency results in shorter roots, smaller shoots and necrotic spots on leaves and in impaired carbon metabolism and decline of chlorophyll and carbon fixation.

The $\mathrm{Mg}$ concentration in silver fir needles was slightly higher in Wisła Forest District (0.07\%) when compared to Ujsoły Forest District (0.05\%) (Fig. 4). The higher $\mathrm{Mg}$ concentration in fir needles $(0.15 \%$ to $0.19 \%)$ was found in the mountains of Poland and Slovakia [6, 9]. The problem of Mg in forest ecosystems was studied e.g. by Hüttl [12] and Hüttl and Schaaf [13]. Their determined threshold for $\mathrm{Mg}$ deficiency was $0.07-0.08 \%$. On the basis of silver fir investigation in about 100 sites within the natural range of the species in Poland, it was found that the contents of $\mathrm{Mg}$ in needles of silver fir trees with a low increment coefficient was lower than $0.12 \%$ [10]. The concentration of $\mathrm{Mg}$ found in needles of silver fir growing in Wisła and Ujsoły Forest District can show the symptoms of $\mathrm{Mg}$ deficit.

$\mathrm{Ca}$ is an essential plant nutrient. It is required for structural roles in cell wall and membranes. The $\mathrm{Ca}$ concentration in silver fir needles amounting to $0.34 \%$ and $0.26 \%$ for Wisła and Ujsoły Forest Districts, respectively can be assessed as a relatively low when compared to another authors who reported the values in the range of $0.76-1.09 \%[6,10]$. The low level of $\mathrm{Ca}$ in the investigated sites can negatively affect the silver fir growth. However, the concentration of $\mathrm{Ca}$ in the soil of both Forest Districts is in the range of $6.53-12.5 \mathrm{mg} \cdot 100 \mathrm{~g}^{-1}$ which was found in the soil of fir stands with normal vitality located in the Carpathian Mountains [10].

The $\mathrm{Na}$ and $\mathrm{S}$ concentrations in the silver fir needles were similar in both sites and they were close to the values obtained in other mountain sites in Poland and the Czech Republic $[6,10,14]$.

In case of bilberry, the concentrations of $\mathrm{Ca}, \mathrm{Na}$ and $\mathrm{S}$ in leaves correspond with values from other unpolluted areas $[15,16]$. The concentrations of $\mathrm{K}$ and $\mathrm{Mg}$ in bilberry leaves, such as silver fir needles, were lower than the values found by the above mentioned authors.

\subsection{The content of heavy metals in leaves and soil}

Contents of heavy metals in soil are presented in Table 4. In the case of $\mathrm{Pb}$ in Wisła Forest District higher average contents of this element was found when compared to Ujsoły Forest District. Concentrations of $\mathrm{Pb}$ in Wisła are close to the permissible value for the protected natural areas [17], which can be the effect of car fumes (due to tourist attendance) or industrial emissions presumably in the 90s of the 20th century. Poland was among the most polluted countries in Europe with a deposition of $\mathrm{Cd}$ and $\mathrm{Pb}$ amounting to $27 \mathrm{t} \cdot \mathrm{year}^{-1}$ and $1100 \mathrm{t} \cdot \mathrm{year}^{-1}$, respectively [18]. Despite this, concentrations of $\mathrm{Cd}$ in both sites are 
close to the average level of this metal in Polish soils $\left(0.5 \mathrm{mg} \cdot \mathrm{kg}^{-1}\right)$ [19]. More than twice Zn contents was found for Wisła Forest District than Ujsoły Forest District but in both cases they do not exceed permissible value for the protected natural areas [17].

Heavy metals measured in aerial parts of trees (leaves, needles) have two potential origins: transfer from soil and atmospheric deposition [20, 21]. Plant-to-soil concentration ratio can be used as a rough indicator of the magnitude of element transfer from soil to plant $[22,23]$.
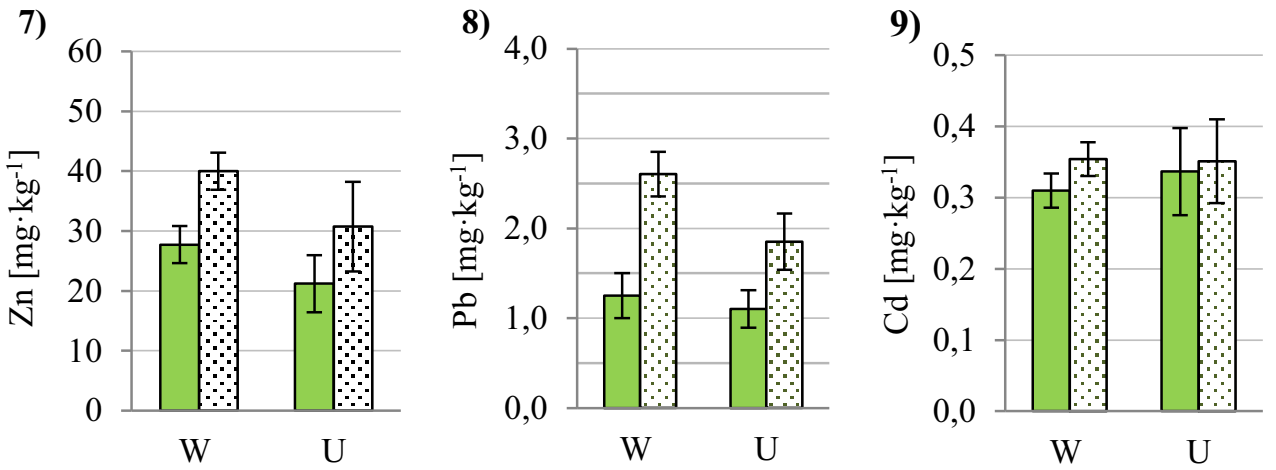

$\square$ A. alba $\square$ V. myrtillus

Fig. 7-9. Contents of $\mathrm{Zn}, \mathrm{Pb}$ and $\mathrm{Cd}$ in needles of silver fir (Abies alba Mill.) and leaves of bilberry (Vaccinium myrtillus L.) (Mean \pm SD; W-Wisła Forest District; U-Ujsoły Forest District).

Contents of heavy metals in soil are presented in figure 7-9.

$\mathrm{Zn}$ plays an important role in the formation of chlorophyll and it takes part in many metabolic processes. Plants uptake actively $\mathrm{Zn}$ proportionally to its concentration in the soil [24]. The critical deficiency contents of $\mathrm{Zn}$ amounts to $>15-20 \mathrm{mg} \cdot \mathrm{kg}^{-1}$ and the toxic level is $100-300 \mathrm{mg} \cdot \mathrm{kg}^{-1}$. Other authors have found at the concentration of above $100 \mathrm{mg} \cdot \mathrm{kg}^{-1}$ the majority of plants show metabolism disorders [25]. The contents of $\mathrm{Zn}$ in leaves shows differences depending on plant species. In this study the concentrations of $\mathrm{Zn}$ in leaves of both species did not exceed physiological needs.

$\mathrm{Zn}$ concentration in silver fir needles from Jodłowice and Gola Wielka was 35 and $3 \mathrm{mg} \cdot \mathrm{kg}^{-1}$, respectively [14]. In other investigations the mean $\mathrm{Zn}$ contents in needles was more than $40 \mathrm{mg} \cdot \mathrm{kg}^{-1}$ [7]. Zn contents in the analyzed samples from Bohemian Forest ranges from 12 to $73 \mathrm{mg} \cdot \mathrm{kg}^{-1}$ with the mean value $41 \mathrm{mg} \cdot \mathrm{kg}^{-1}$ [6]. In all the said works, concentration of $\mathrm{Zn}$ in needles was higher than the one obtained in this paper. In $V$. myrtillus the quantity of $\mathrm{Zn}$ in leaves was higher than in $A$. alba and it was $40 \mathrm{mg} \cdot \mathrm{kg}^{-1}$ in Wisła Forestry and $30 \mathrm{mg} \cdot \mathrm{kg}^{-1}$ in Ujsoły Forestry. Smaller $\mathrm{Zn}$ values in leaves of $V$. myrtillus were obtained by Mróz and Demczuk [16] in the polluted areas. Similar values were obtained by Kozancka $-20 \mathrm{mg} \cdot \mathrm{kg}^{-1}[15]$.

The critical limit of $\mathrm{Pb}$ toxicity for plants is $30-300 \mathrm{mg} \cdot \mathrm{kg}^{-1}$ and a wide range of values can be contributed to high tolerance of some species (mainly growing in contaminated areas) to $\mathrm{Pb}$. For example, native species of Betula pendula and Pinus sylvestris have a fairly good condition and have the ability of spontaneous spreading by seeds under high contamination of $\mathrm{Pb}$ and $\mathrm{Zn}$ [26]. In hereby examination, contents of $\mathrm{Pb}$ in silver fir does not exceed $2.6 \mathrm{mg} \cdot \mathrm{kg}^{-1}$. In Szymura's research [14] in current year needles of $A$. alba 9.8 and $10 \mathrm{mgPb} \cdot \mathrm{kg}^{-1}$ was noticed in Jodłowice and Gola Wielka. Higher values of $\mathrm{Pb}$ were noticed in $V$. myrtillus. When comparing coefficients of $\mathrm{Pb}$ bioaccumulation $(\mathrm{Pb}$ contents in 
leaves $/ \mathrm{Pb}$ contents in soil) in both species ( $V$. myrtillus $0.047>$ A. alba 0.026 ), higher ability to bioaccumulation of $\mathrm{Pb}$ at $V$. myrtillus can be noticed, which indicates that it is a better bioindicator for this element. Additionally, in Wisła Forestry higher values of $\mathrm{Pb}$ in soil were noticed than in Ujsoly, which is reflected in the results.

Symptoms of the harmful effect of $\mathrm{Cd}$ in plants occur at the concentration of 5-30 mg kg $\mathrm{kg}^{-1}$ [22], in sensitive plants the value of $5 \mathrm{mg} \cdot \mathrm{kg}^{-1} \mathrm{seems}$ to be toxic [27].The $0.2 \mathrm{mg} \cdot \mathrm{kg}^{-1}$ level in plants is considered to be a highly elevated concentration according to the scale proposed by Arndt [28]. The mean Cd concentration in spruce needles collected from all 23 Polish national parks was $0.18 \mathrm{mg} \cdot \mathrm{kg}^{-1}$ [29]. In hereby paper, concentration of $\mathrm{Cd}$ in leaves of both species was similar (about $0.3 \mathrm{mg} \cdot \mathrm{kg}^{-1}$ ). The obtained results show the area of research was or still is submitted to anthropopression. Smaller values for bilberry from the ones obtained in this paper were noticed by Mróz and Demczuk [16] in the unpolluted areas $0.02-0.06 \mathrm{mg} \cdot \mathrm{kg}^{-1}$. Szymura [14] noticed in current year needles of A. alba contents at the level of $1.02 \mathrm{mg} \cdot \mathrm{kg}^{-1}$ in Jodłowice and $2.17 \mathrm{mg} \cdot \mathrm{kg}^{-1}$ in Gola Wielka.

\subsection{Conclusions}

- Concentration of macronutrients found in leaves of bilberry and silver fir needles is relatively low (near a deficit value) when compared to literature data.

- A slight exceedance of $\mathrm{Pb}$ concentration level recommended for the protected areas was found in the soil of the Wisła Forest District.

- Higher level of $\mathrm{Pb}$ accumulation in bilberry leaves when compared to silver fir needles was found which suggests the use of bilberry leaves as a bioindicator of this element in Silesian and Żywiec Beskidy.

The study was carried out under the project "Determination of habitat conditions and vitality of silver fir (Abies alba Mill.) with recommendation of areas suitable for its cultivation in Silesian and Żywiec Beskidy" ordered by the Regional Directorate of State Forests in Katowice and supported by the Voivodeship Fund for Environmental Protection and Water Management, Katowice.

\section{References}

1. T. Staszewski, P. Kubiesa, Beskydy 1, 77-84 (2008)

2. C. Reimanna, F. Kollerb, G. Kashulinac, H. Niskavaarad, P. Englmaiere, Environ Pollut 115, 239-252 (2001)

3. M. Salemaa, J. Derome, H.S. Helmisaari, T. Nieminen, I. Vanha-Majamaa, Sci Total Environ 324, 141-160 (2004)

4. A. Brekken, E. Steinnes, Sci Total Environ 326,181-195 (2004)

5. D. Białońska, A. Zobel, M. Kuraś, T. Tykarska, K. Sawicka-Kapusta, Water Air Soil Poll 181, 123-133 (2007)

6. R. Novotný, D. Černý, V. Šrámek, J Trop For Sci 56, 381-388 (2010)

7. L. Gandois, A. Probst, Chemosphere 87, 204-210 (2012)

8. R. Bäumler, T. Goerttler, W. Zech, Forstwiesenschaftliches Centralblatt 114, 30-39 (1995)

9. B. Maňkovská, B. Godzik, O. Badea, Y. Shparyk, P. Moravčík, Env Poll 130, 41-54 (2004)

10. J. Zawada, Prace Instytutu Badawczego Leśnictwa A, 849 (1998) 
11. M. Musio, N. Augustin, H.P. Kahle, A. Krall, E. Kublin, R. Unseld, K. Wilpert, Ecol Model 179, 307-316 (2004)

12. R.F. Hüttl, Kali-Briefe 17, 1-7 (1986)

13. R.F. Hüttl, W. Schaaf,N Deficiency in Forest Ecosystems (London, Kluwer Academic Publishers: 362, 1997)

14. T. Szymura, Trees 23, 211-217 (2009)

15. T. Kozanecka, J. Chojnicki, W. Kwasowski, Pol J Environ Stud 11, 395-399 (2002)

16. L. Mróz, M. Demczuk, Pol J Ecol 58, 475-486 (2010)

17. Official Journal of Law (2002). No. 165, Clause 1359

18. K.D. Van den Hout, D.J. Bakker, J.J.M. Berdowski, J.A. Van Jaarsweld, G.J. Reinds, J. Bril, A. Breeuwsma, J.E. Groenenberg, W. De Vries, J.A. Van Pagee, M. Villars, C.J. Sliggers, Water Air Soil Poll 109, 357-396 (1999)

19. J. Lis, A. Pasieczna, Atlas geochemiczny Polski 1:2 500000 (PIG, Warszawa 1995).

20. A. Kabata-Pendias, Geoderma 122, 143-149 (2004)

21. J. Klaminder, R. Bindler, O. Emteryd, I. Renberg, Geochim Cosmochim Ac 69, 2485-2496 (2005)

22. A. Kabata-Pendias, H. Pendias, Trace elements in soils ( $3^{\text {rd }}$ Ed. Boca Raton, London, New York, CRC Press, 413, 2001)

23. S. Ehlken, G. Kirchner, J Environ Radioact 58 (2002)

24. B. Hafeez, Y.M. Khanif, M. Salem, American Journal of Experimental Agriculture 3, 374-391 (2013)

25. M.H. Zenk, Gene 179, 21-30.(1996)

26. K. Skubała, Arch Environ Prot 37, 57-74 (2011)

27. I. Ahmad, M.J. Akhtar, Z.A. Zahir, A. Jamil, Pak J Bot 44, 1569-1574 (2012)

28. U. Arndt, W. Nobel, B. Schweizer, Bioindikatoren. Möglichkeiten, Grenzen und neue Erkenntnisse (Ulmer Verlag, Stuttgart 1987)

29. T. Staszewski, W. Łukasik, P. Kubiesa, Environ Monit Assess 184, 4597-4608 (2012) 